\title{
The comparison of biomarkers released by hydropyrolysis and Soxhlet extraction from source rocks of different maturities
}

\author{
WU LiangLiang ${ }^{1,2}$, LIAO YuHong ${ }^{1}$, FANG YunXin $^{1} \&$ GENG AnSong ${ }^{1 *}$ \\ ${ }^{1}$ State Key Laboratory of Organic Geochemistry, Guangzhou Institute of Geochemistry, Chinese Academy of Sciences, \\ Guangzhou 510640, China; \\ ${ }^{2}$ Graduate University of Chinese Academy of Sciences, Beijing 100049, China
}

Received April 26, 2012; accepted June 19, 2012; published online August 7, 2012

\begin{abstract}
The Permian Dalong Formation $\left(\mathrm{P}_{2} d\right)$ source rocks from the mature Guangyuan outcrop section and the overmature Wangcang outcrop section in Sichuan Basin were selected. The Soxhlet extraction and kerogen catalytic HyPy were conducted on the $\mathrm{P}_{2} d$ source rocks. The biomarkers obtained by both methods were compared to discuss their difference and the influence extent of thermal maturation on covalently bound biomarkers. The results show that covalently bound biomarkers can hardly be correlated to the corresponding free biomarkers due to severe thermal alterations and/or interference of migrated hydrocarbons in both outcrop sections and thermal maturation have much lower influence on covalently bound biomarkers in kerogens than on free biomarkers in Soxhlet extracts. The application of HyPy in study of biomarker geochemistry can reduce the thermal maturation effect on biomarkers $\left(R_{0} \leqslant 2.4 \%\right)$ to a greater extent and the interference of migrated hydrocarbons between interbedded layers. The covalently bound biomarkers released by HyPy are useful in the study of biomarker geochemistry and oil-source correlation on high-overmature source rocks.
\end{abstract}

hydropyrolysis, thermal maturation, Sichuan Basin, Dalong Formation

Citation: Wu L L, Liao Y H, Fang Y X, et al. The comparison of biomarkers released by hydropyrolysis and Soxhlet extraction from source rocks of different maturities. Chin Sci Bull, 2013, 58: 373-383, doi: 10.1007/s11434-012-5377-7

Biomarkers are organic compounds derived from biomass and extensively exist in sediments and sedimentary rocks $[1,2]$. These organic molecules, especially steranes and terpanes, with complex structure and biogenetic indication, have been widely applied in the study of petroleum geochemistry. In the process of hydrocarbon generation and expulsion, the expelled oil can inherit the biomarker characteristics of the source rocks by retaining the carbon skeleton of geo-macromolecule [3]. Oil-source correlations are based on the concept that biomarker parameters can indicate source and depositional environment and reflect thermal evolution of organic matters.

Most of the marine source rocks in South China are at high-overmature stage [4,5]. The biomarkers obtained by Soxhlet extraction from high-overmature source rocks or

\footnotetext{
*Corresponding author (email: asgeng@gzb.ac.cn)
}

bitumens are too low to satisfy the requirement of instrumental analysis [4,6-8], and are easily polluted by recent sediments and migrated hydrocarbons to discount their reliability. Meanwhile, the source-related biomarker parameters extracted from high-overmature source rocks would become a similar developing pattern and can not represent the original characteristic of organic matters [4]. Furthermore, it is difficult to get enough biomarkers by simple pyrolysis or chemical degradation from high-overmature source rocks due to their being hydrogen poor [8]. Thus it is problematic to get molecular geochemical information from high-overmature source rocks and to correlate them with potential oil reservoir by routine methods.

Fixed-bed Hydropyrolysis (HyPy) refers to an opensystem pyrolysis at high hydrogen pressures $(>10 \mathrm{MPa})$ in the presence of a dispersed sulphided molybdenum catalyst. Previous studies [8-15] suggested that HyPy can release 
higher yield of extractable organic matter (EOM) than Soxhelt extraction at various maturities. Love et al. [9] implied HyPy can maximize the yields of covalently bound aliphatic biomarkers without adversely affecting their stereochemistries from low mature kerogen. Murray et al. [12] suggested that the high hydrogen pressure used in HyPy appears to suppress the potential ability of clay minerals to promote cracking and isomerisation during pyrolysis. Some other studies [13,16-18] further suggested that the covalently bound biomarkers released by HyPy from kerogen usually show characteristics of low maturity. Liao et al. [18] used HyPy to release covalently bound biomarkers from artificial thermal altered bitumens of various maturities (easy $R_{0}: 1.08 \%-2.86 \%$ ). The results by Liao et al. [18] indicated that those biomarkers are much more insensitive to thermal alteration than free biomarkers. HyPy are also used to release covalently bound biomarkers from high-overmature source rocks. For example, Sun et al. [8] used covalently bound biomarkers released by HyPy to study the palaeoenvironment of source rocks from the Tarim Basin. Therefore, HyPy seems to be a promising method to recover original geochemical information from high-overmature source rocks. However, some basic mechanisms concerning high-overmature source rocks need to be elucidated. First, whether the covalently bound biomarkers released by HyPy can be directly compared with the biomarkers obtained by Soxhlet extraction at high-over maturity stage? Second, whether the availability of the covalently bound biomarkers from kerogens used in source characterization and oilsource correlation can be influenced by thermal maturation?
In the Sichuan Basin, the Permian Dalong Formation $\left(\mathrm{P}_{2} d\right)$ source rocks comprise marine dark silicalites and mudstones that are interbedded [19-22], and mainly occur in the Guangyuan-Wangcang trough and the Western Hubei-Chengkou trough [19-21,23,24]. Most of the $\mathrm{P}_{2} d$ source rocks in the Sichuan Basin (such as in the Wangcang outcrop section) are at high-overmature stage, with very low amount of EOM. However, the $\mathrm{P}_{2} d$ source rocks in the Guangyuan outcrop section are still in oil-generative window due to the uplift of Longmen Mountain. The $\mathrm{P}_{2} d$ source rocks in the Wangcang and the Guangyuan outcrop sections shared very similar depositional environments, since they occur in the same trough. Therefore, the $\mathrm{P}_{2} d$ source rocks from the Guangyuan and the Wangcang outcrop sections were selected for Soxhlet extraction and HyPy. The characteristics of the biomarkers released by HyPy were compared with those by Soxhlet extraction and the influences of thermal maturation on covalently bound biomarkers were discussed.

\section{Samples and experiments}

\subsection{Source rock samples}

The Upper-Permian Dalong Formation $\left(\mathrm{P}_{2} d\right)$ source rocks from the Guangyuan (GY series) and the Wangcang (WC series) outcrop sections shared very similar depositional environment but with different maturity, in the Sichuan Basin, China, were selected for this study (Figure 1). The $\mathrm{P}_{2} d$ Formation in the Sichuan Basin are typically marine dark

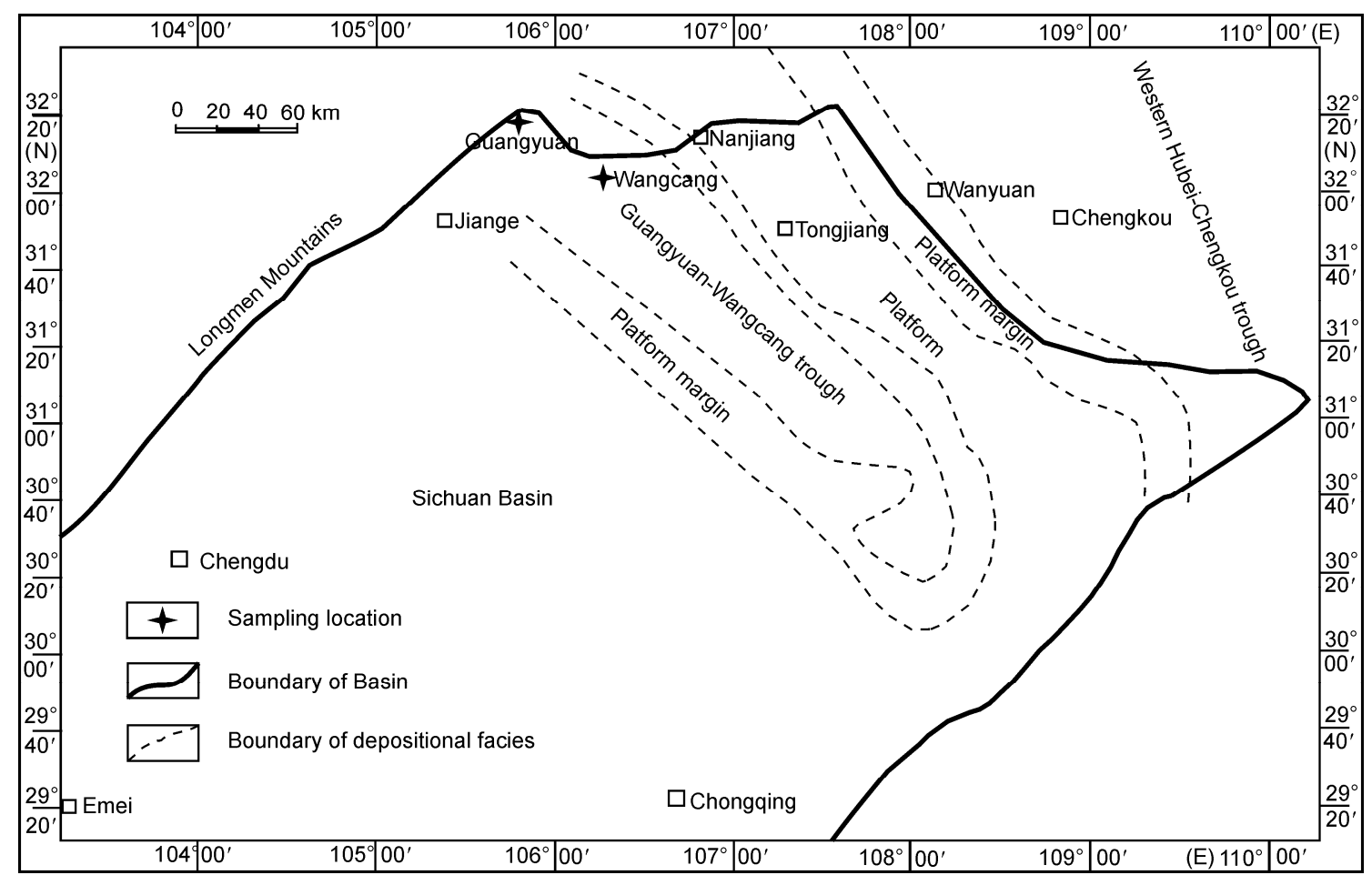

Figure 1 The geological map showing sampling location. 
silicalite layers interbedded with mudstone layers [19,20]. Silicalites and mudstones are thought to be deposited in different depositional environments in that silicalites had deeper depositional water-depth than mudstones [25]. All the $\mathrm{P}_{2} d$ source rocks were sampled chronologically from old to young strata on each outcrop section, with intervals from $0.2 \mathrm{~m}$ to $0.5 \mathrm{~m}$. The basic information of the samples is shown in Table 1. The $T_{\max }$ values of the GY series samples range from 436 to $438^{\circ} \mathrm{C}$, with measured vitrinite reflectance $\left(R_{\mathrm{o}}\right)$ about $0.6 \%$, implying that the GY series samples are still in oil-generative window. The WC series samples are overmature, with the $T_{\max }$ values ranging from 552 to $603^{\circ} \mathrm{C}$. $R_{\mathrm{o}}$ values of the samples from the Permian section of the Wangcang area measured by Liang et al. ${ }^{1)}$ are in the range of $1.88 \%-2.39 \%$. Micrinites are dominant macerals in the kerogens of the $\mathrm{P}_{2} d$ source rocks. Vitrinite can be occasionally found in the GY series kerogens but at low concentration. Meanwhile, their bulk $\delta^{13} \mathrm{C}$ are in very narrow range of $-27.1 \% o^{-}-28.4 \%$. The kerogens in the $\mathrm{P}_{2} d$ source rocks are of type II in the study area.

\subsection{Dry Pyrolysis and HyPy experiment}

The dry pyrolysis experiments were conducted on the kerogen GY-8. The kerogen was sealed in glass tubes under the protection of nitrogen gas. The tubes were then heated for $72 \mathrm{~h}$ at 400,430 and $460^{\circ} \mathrm{C}$, respectively. The calculated vitrinite reflectance $\left(R_{\mathrm{o}}\right)$ by Easy $\% R_{\mathrm{o}}$ method [26] for the kerogen heated at 400,430 and $460^{\circ} \mathrm{C}$ were $1.74 \%, 2.27 \%$ and $2.86 \%$, respectively (the maturities of $\mathrm{P}_{2} d$ samples from the WC series are in this range). The pyrolysates were recovered by adding dichloromethane (DCM), and then sonicated and washed repeatedly.

The source rock samples were crushed to 80 mesh and then extracted with a mixture of DCM and methanol (93:7, $\mathrm{v} / \mathrm{v})$ at $46^{\circ} \mathrm{C}$ for $72 \mathrm{~h}$. Then, those rock powders were treated by acid to get kerogens. The kerogen samples $(0.3-0.8 \mathrm{~g})$ for HyPy were Soxhlet extracted by ternary solvent (benzene/acetone/methanol=5:5:2) for 2 weeks to remove solu- ble organic matter. HyPy apparatus were described by Love et al. [9]. The solvent-extracted kerogens were impregnated with an aqueous solution of ammonium dioxydithiomolybdate $\left[\left(\mathrm{NH}_{4}\right)_{2} \mathrm{MoO}_{2} \mathrm{~S}_{2}\right]$ to give a nominal loading of molybdenum of $5 \mathrm{wt} \%$. Then, the kerogen powders with catalyst were loaded into stainless steel reactor to do hydropyrolysis using a hydrogen pressure of 15.0 MPa. A hydrogen flow of $4 \mathrm{~L} / \mathrm{min}$, measured at ambient temperature and pressure, was used through the reactor. The kerogen powder was then vacuum-dried for subsequent HyPy experiment. HyPy experiment involves two steps, both steps were conducted in the same hydrogen pressure and hydrogen flow. At first, the sample was pyrolysed with resistive heating from ambient temperature programmed to $300^{\circ} \mathrm{C}(5 \mathrm{~min})$ at $250^{\circ} \mathrm{C} / \mathrm{min}$ rate, to completely remove the adsorbed hydrocarbons and the weaker covalent bonds leaving the stronger bonds for HyPy [9]. After all of the weaker covalently bound compounds were removed from the kerogen, the collecting tube was replaced. The second heating run was employed from ambient temperature programmed to $250^{\circ} \mathrm{C}$ at $300^{\circ} \mathrm{C} / \mathrm{min}$ rate, then increase to $520^{\circ} \mathrm{C}$ at $8^{\circ} \mathrm{C} / \mathrm{min}$ rate, and finally kept at $520^{\circ} \mathrm{C}$ for $5 \mathrm{~min}$. Before each HyPy experiment, the collecting tube of HyPy system was washed with DCM and then heated at $600^{\circ} \mathrm{C}$ for $4 \mathrm{~h}$. A HyPy blank experiment was performed before running real samples. The details of HyPy experiments can be referred to Sun et al. [8] and Liao et al. [18]. The hydropyrolysates were collected by clean gel silica in a liquid nitrogen cold trap and recovered by DCM/ methanol $(93: 7, \mathrm{v} / \mathrm{v})$ for subsequent fractionation and analysis.

The pyrolysates and the Soxhlet extracts as well as the hydropyrolysates of the $\mathrm{P}_{2} d$ source rocks were all conducted on the following process. The details of Soxhlet extraction can be referred to Zhang et al. [27] and Liao et al. [28]. The asphaltenes were precipitated from the extracts by adding 50:1 (v/v) cold $n$-hexane, and then removed by centrifugation. The maltene fractions were fractionated by silica/alumina $(3: 1, \mathrm{v} / \mathrm{v})$ column chromatography into saturate, aromatic and polar fractions, which were eluted with

Table 1 The basic information of the source rocks

\begin{tabular}{|c|c|c|c|c|c|c|c|c|}
\hline Sample ID & Lithology & $\delta^{13} \mathrm{C}(\% \circ)$ & $R_{\mathrm{o}}(\%)$ & $T_{\mathrm{OC}}(\%)$ & $S 1$ & $S 2$ & $T_{\max }\left({ }^{\circ} \mathrm{C}\right)$ & $\mathrm{HI}$ \\
\hline GY-3 & mudstone & -28.4 & - & 3.54 & 0.43 & 7.29 & 437 & 206 \\
\hline GY-8 & silicalite & -27.6 & 0.58 & 8.75 & 1.22 & 30.06 & 438 & 343 \\
\hline GY-9 & siliceous mudstone & -27.1 & - & 4.58 & 0.48 & 12.68 & 436 & 300 \\
\hline GY-17 & mudstone & -27.8 & 0.68 & 3.67 & 0.61 & 13.31 & 438 & 357 \\
\hline WC-4A & silicalite & -28.1 & - & 2.81 & 0 & 0.1 & 603 & 5 \\
\hline WC-5 & mudstone & -27.5 & - & 4.07 & 0.04 & 0.18 & 601 & 5 \\
\hline WC-6A & silicalite & -27.1 & - & 8.54 & 0.01 & 0.15 & 552 & 2 \\
\hline WC-6B & mudstone & -27.3 & - & 7.10 & 0 & 0.15 & 556 & 2 \\
\hline
\end{tabular}

1) Liang D G, Chen J P, Zhao Z, et al. Evaluation on efficient source rock of complex structure area in Southern China (unpublished report, in Chinese). SINOPEC Exploration Southern Company, 2007 
$n$-hexane, DCM $/ n$-hexane $(3: 1, \mathrm{v} / \mathrm{v})$ and DCM/methanol $(2: 1, \mathrm{v} / \mathrm{v})$, respectively. The saturated hydrocarbon fractions were analyzed by GC-MS. The saturated hydrocarbon fraction resulting from HyPy blank experiment and subsequent column chromatography is also analyzed by GC-MS. There are no steranes and terpanes identified (Figure 2).

\subsection{Instrumental}

Analysis of the saturated biomarkers was conducted using a Thermo Scientific Trace GC Ultra gas chromatography coupled to a Thermo Scientific Trace DSQ II mass spectrometer. A DB-1 fused silica capillary column $(60 \mathrm{~m} \times$ $0.32 \mathrm{~mm}$ i.d. $\times 0.25 \mu \mathrm{m}$ film thickness) was used. The GC oven was held isothermally at $70^{\circ} \mathrm{C}$ for $2 \mathrm{~min}$, programmed to $290^{\circ} \mathrm{C}$ at $4^{\circ} \mathrm{C} / \mathrm{min}$ rate, with a final holding time of 30 min. Helium was used as carrier gas with a constant flow rate of $1.5 \mathrm{~mL} / \mathrm{min}$. The ion-source temperature was $250^{\circ} \mathrm{C}$, and the temperature of injector was $290^{\circ} \mathrm{C}$. The ion source was operated in the electron impact (EI) mode with electron energy of $70 \mathrm{eV}$.

\section{Results and discussion}

In both the Guangyuan outcrop section (GY series) and the Wangcang outcrop section (WC series), the TOC normalized yields of Soxhlet extraction and HyPy and their saturates/aromatics ratios are listed in Table 2. The TOC normalized EOM yields by Soxhlet extraction from the WC series are in the range of $0.7-1.2 \mathrm{mg} / \mathrm{g}$ TOC, much lower than those from the GY series (45.4-92.6 mg/g TOC) due to the high maturity. The TOC normalized EOM yields by HyPy are higher than those by Soxhlet extraction for both outcrop sections. The TOC normalized EOM yields by HyPy are 4-9 times those by Soxhlet extraction in the GY series. However, the TOC normalized EOM yields by HyPy are 37-168 times those by Soxhlet extraction in the WC series. In hydropyrolysates, saturated hydrocarbon fractions make $9.4 \%-27.9 \%$ of total EOM for the GY series, contrast to $0.2 \%-2.7 \%$ for the WC series. It indicates that

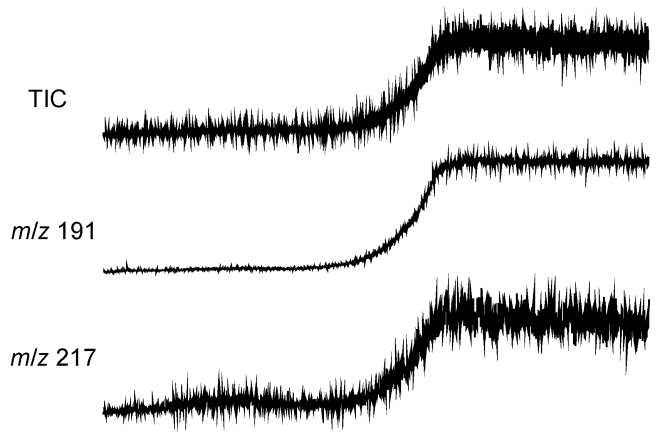

Figure 2 TIC, $m / z, 191$ and $m / z 217$ mass chromatograms of HyPy blank.

the kerogen is high in aromaticity and there are few aliphatic structures in the kerogen structure at high-overmature stages due to severe decomposition and condensation.

\subsection{Source-related biomarker parameters}

The steranes are considered to be sourced from sterols in eukaryotic organisms $[3,29]$. The sterane ternary diagram of $\mathrm{C}_{27-29} \alpha \alpha \alpha 20 \mathrm{R}$ is commonly used to distinguish groups of crude oils from different source rocks or different organic facies of the same source rock [3,30,31], and also extensively used to show relationships between oils and/or source rocks [32,33].

There are significant differences in the distribution of $\mathrm{C}_{27-29} \alpha \alpha \alpha 20 \mathrm{R}$ steranes between the GY and the WC series. The distribution of $\mathrm{C}_{27-29} \alpha \alpha \alpha 20 \mathrm{R}$ steranes in all $\mathrm{P}_{2} d$ source rock extracts from the GY series show similar "V" shape $\left(\mathrm{C}_{27} \approx \mathrm{C}_{29}>\mathrm{C}_{28}\right)$, which was also reported by Tenger et al. [21]. However, the distribution of $\mathrm{C}_{27-29} \alpha \alpha \alpha 20 \mathrm{R}$ steranes in $\mathrm{P}_{2} d$ source rock extracts from the WC series show similar "L" shape $\left(\mathrm{C}_{27}>\mathrm{C}_{29}>\mathrm{C}_{28}\right)$ (Figure 3). Study by Lu et al. [34] suggested that secondary cracking in thermal maturation may alter the distribution of $\mathrm{C}_{27-29} \alpha \alpha \alpha 20 \mathrm{R}$ steranes because $\mathrm{C}_{29}$ and/or $\mathrm{C}_{28} \alpha \alpha \alpha 20 \mathrm{R}$ steranes show lower thermal stability than $\mathrm{C}_{27} \alpha \alpha \alpha 20 \mathrm{R}$ steranes. Thus the sample GY-8 $\left(R_{\mathrm{o}}\right.$ : $0.58 \%$ ) was selected for artificial thermal maturation simulations to investigate the influence of thermal maturation on the distribution of $\mathrm{C}_{27-29} \alpha \alpha \alpha 20 \mathrm{R}$ steranes in the Soxhlet

Table 2 The TOC normalized yields of Soxhlet extraction and HyPy

\begin{tabular}{|c|c|c|c|c|c|c|c|}
\hline \multirow{2}{*}{ Sample ID } & \multicolumn{3}{|c|}{ Soxhlet extracts (mg/g TOC) } & \multicolumn{3}{|c|}{ Hydropyrolysates $\left(520^{\circ} \mathrm{C}, \mathrm{mg} / \mathrm{g}\right.$ TOC) } & \multirow{2}{*}{$\begin{array}{l}\text { Hydropyrolysate/ } \\
\text { Soxhlet extract }\end{array}$} \\
\hline & EOM (mg/g TOC) & Saturates $(\%)$ & Saturates/aromatics & EOM (mg/g TOC) & Saturates $(\%)$ & $\overline{\text { Saturates/aromatics }}$ & \\
\hline GY-3 & 92.4 & 12.9 & 0.85 & 374.6 & 23.9 & 0.66 & 4 \\
\hline GY-9 & 82.7 & 11.2 & 0.28 & 472.7 & 27.9 & 0.96 & 6 \\
\hline GY-17 & 45.4 & 18.3 & 0.40 & 205.0 & 9.4 & 0.12 & 5 \\
\hline WC-4A & 0.7 & 14.3 & 0.25 & 32.9 & 2.7 & 0.05 & 47 \\
\hline WC-5 & 1.2 & 8.3 & 0.17 & 44.7 & 1.3 & 0.03 & 37 \\
\hline WC-6A & 0.7 & 14.3 & 1.00 & 117.3 & 0.2 & 0.01 & 168 \\
\hline WC-6B & 1.0 & 10.0 & 0.14 & 146.4 & 0.5 & 0.01 & 146 \\
\hline
\end{tabular}




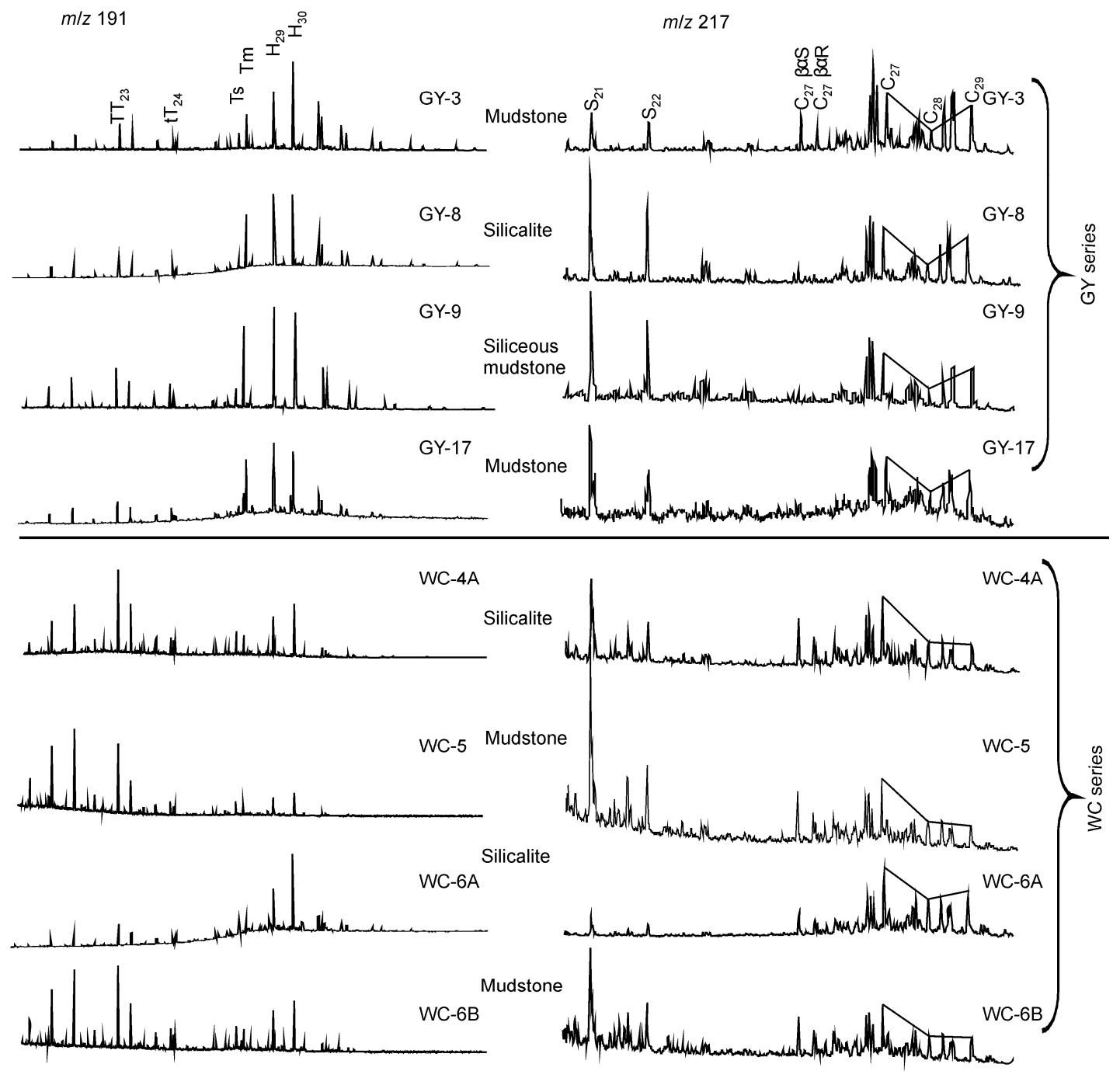

Figure $3 \mathrm{~m} / \mathrm{z}, 191$ and $\mathrm{m} / \mathrm{z} 217$ mass chromatograms of the Soxhlet extracts from the Dalong Formation source rocks.

extract of $\mathrm{P}_{2} d$ source rock. The results show that the distribution of $\mathrm{C}_{27-29} \alpha \alpha \alpha 20 \mathrm{R}$ steranes change gradually from "V" shape in original extracts to "L" shape in the $72 \mathrm{~h}$ artificial thermal maturation products at $400-460^{\circ} \mathrm{C}$ (Figure 4) due to a quicker decrease in $\mathrm{C}_{29}$ sterane (Figure 5(a)). Such variations resulting from increasing maturity can also be clearly seen in the sterane ternary diagram of $\mathrm{C}_{27-29} \alpha \alpha \alpha 20 \mathrm{R}$ in Soxhlet extracts from both outcrop sections. Namely, the abundance of $\mathrm{C}_{29}$ sterane relative to $\mathrm{C}_{27}$ sterane in the Soxhlet extracts of the GY series are much higher than that of the WC series (Figure 5(b)). Therefore, the difference in the distribution of $\mathrm{C}_{27-29} \alpha \alpha \alpha 20 \mathrm{R}$ steranes in the Soxhlet extracts between the GY and the WC series can be attributed to the difference in maturity. It indicated that the sourcerelated biomarker parameters in Soxhlet extracts of highovermature source rocks can be altered by thermal maturation and the original characteristic of organic matters may also be altered.

The biomarker assignments are listed in Table 3.

The $\mathrm{P}_{2} d$ source rocks in the Sichuan Basin are typically

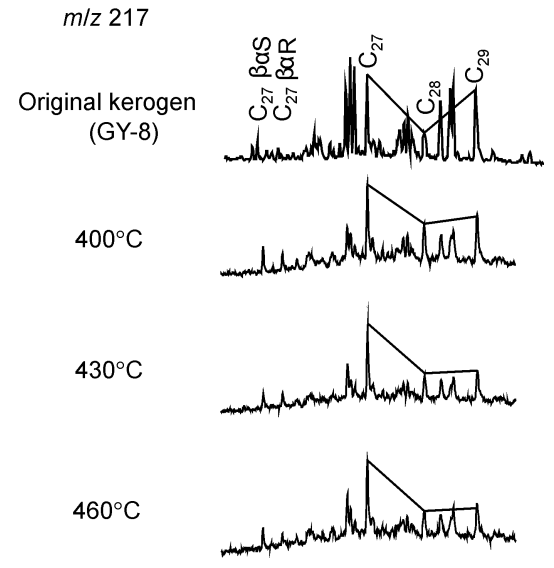

Figure $4 \mathrm{~m} / \mathrm{z} 217$ mass chromatograms of the Soxhlet extracts of original sample and the pyrolysates of artificial simulation series.

marine dark silicalite layers interbedded with mudstone layers. In hydropyrolysates, the distribution of $\mathrm{C}_{27-29} \alpha \alpha \alpha 20 \mathrm{R}$ steranes in the silicalite layers have a $\mathrm{C}_{29}$ advantage, while 
those in the mudstones layer show a $\mathrm{C}_{27}$ advantage (Figure 6). The hydropyrolysates from mudstone layers and that from silicalite layers are in two different groups in the sterane ternary diagram (Figure 5(c)). Interestingly, the hydropyrolysates of the siliceous mudstone layer sample GY-8 is in between the two groups (Figure 5(c)). The hydropyrolysates from the samples with the same lithology have similar distribution of $\mathrm{C}_{27-29} \alpha \alpha \alpha 20 \mathrm{R}$ (Figure 5(c)) in spite of different maturities. It seems that the depositional envi- ronment should be the major factor controlling the distribution of the covaltently bound $\mathrm{C}_{27-29} \alpha \alpha \alpha 20 \mathrm{R}$ steranes (Figures 5(c) and 6). The distribution of covalently bound steranes released by HyPy from high-overmature source rocks are similar to those from the mature source rocks for the protection of macromolecular structure $[17,35]$. Therefore, the covalently bound steranes released by HyPy from the overmature Permian Dalong Formation source rocks in the WC series $\left(R_{0} \leqslant 2.4 \%\right)$ can still represent the original characteristic
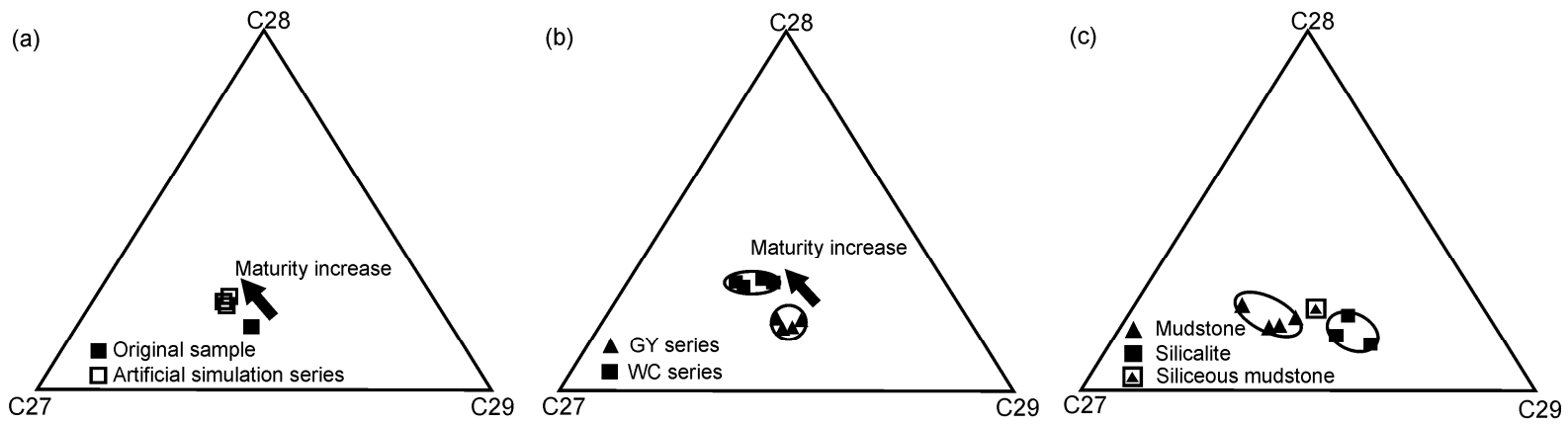

Figure 5 The ternary plot of $\mathrm{C}_{27-29} \alpha \alpha \alpha 20 \mathrm{R}$ sterane distribution. (a) Soxhlet extracts of GY-8 and artificial thermal maturation products; (b) Soxhlet extracts. (c) Hydropyrolysates.
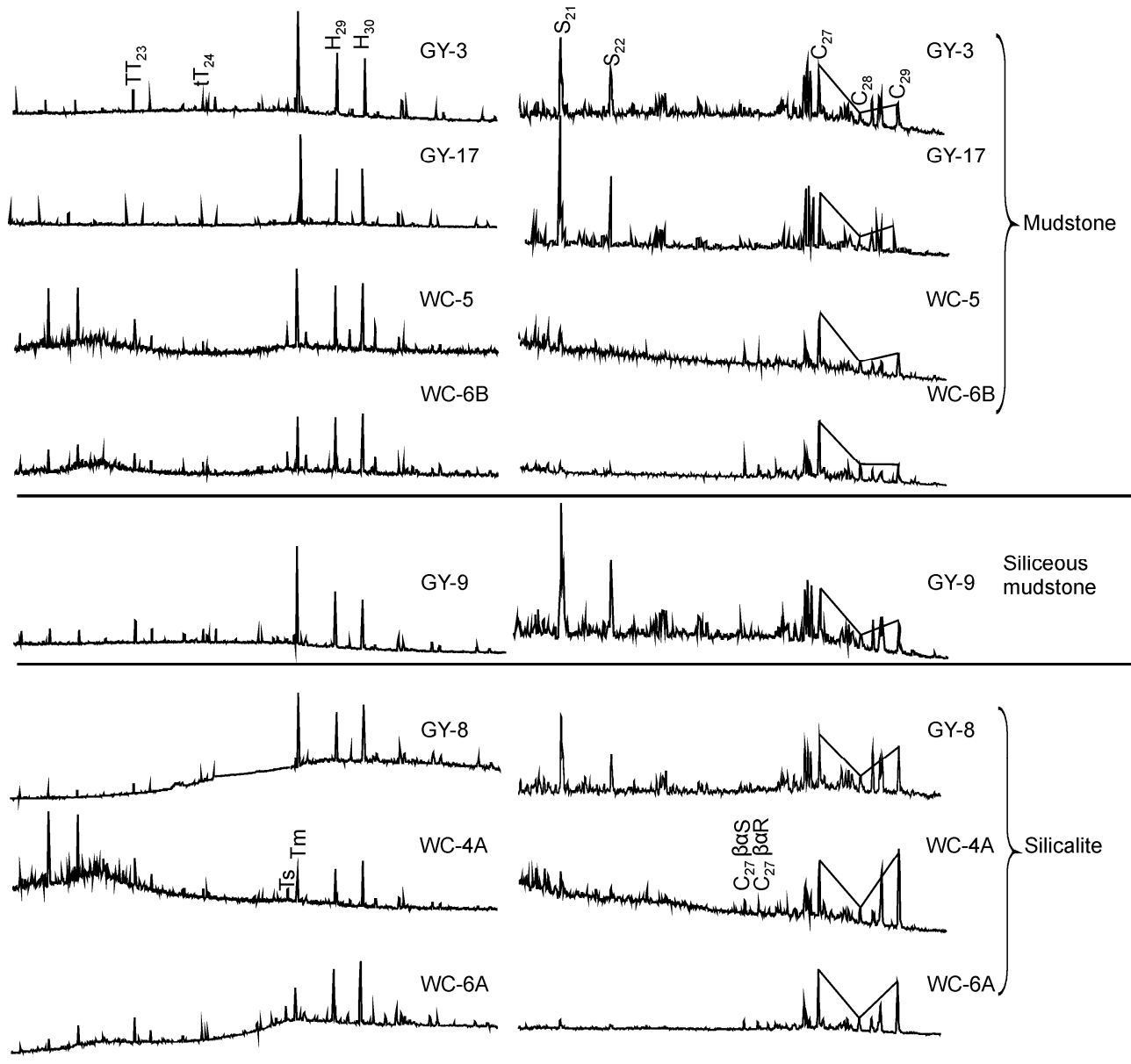

Figure $6 \mathrm{~m} / \mathrm{z}, 191$ and $\mathrm{m} / \mathrm{z}, 217$ mass chromatograms of the hydropyrolysates from $\mathrm{P}_{2} d$ source rocks. 
Table 3 Biomarker assignments

\begin{tabular}{cl}
\hline Peak & \multicolumn{1}{c}{ Compound } \\
\hline $\mathrm{TT}_{23}$ & $\mathrm{C}_{23}$-tricyclic terpane \\
$\mathrm{tT}_{24}$ & $\mathrm{C}_{24}$-tetracylic terpane \\
$\mathrm{H}_{29}$ & $\mathrm{C}_{29}-\alpha \beta$ hopane \\
$\mathrm{H}_{30}$ & $\mathrm{C}_{30}-\alpha \beta$ hopane \\
$\mathrm{Ts}$ & $\mathrm{C}_{27} 17 \alpha$-trisnorhopane \\
$\mathrm{Tm}$ & $\mathrm{C}_{27} 18 \alpha$-trisnorhopane \\
$\mathrm{C}_{27}$ & $\mathrm{C}_{27}-\alpha \alpha \alpha \mathrm{R}$ cholestane \\
$\mathrm{C}_{28}$ & $\mathrm{C}_{28}-\alpha \alpha \alpha \mathrm{R}$ ergostane \\
$\mathrm{C}_{29}$ & $\mathrm{C}_{29}-\alpha \alpha \alpha \mathrm{R}$ stigmastane \\
$\mathrm{C}_{27} \beta \alpha \mathrm{S}$ & $\mathrm{C}_{27} \beta \alpha \mathrm{S}$ diacholestane \\
$\mathrm{C}_{27} \beta \alpha \mathrm{R}$ & $\mathrm{C}_{27} \beta \alpha \mathrm{R}$ diacholestane \\
$\mathrm{S}_{21}$ & $\mathrm{C}_{21}$ Pregnane \\
$\mathrm{S}_{22}$ & $\mathrm{C}_{22}$ Homopregnane \\
\hline
\end{tabular}

of organic matter.

As discussed above, there are differences in the distribution of covalently bound $\mathrm{C}_{27-29} \alpha \alpha \alpha 20 \mathrm{R}$ steranes between silicalite layers and mudstone layers from the GY series (Figure 6). However, in the Soxhlet extracts of both silicalite layers and mudstone layers from the GY series, $C_{27}$ $\alpha \alpha \alpha 20 \mathrm{R}$ sterane shows similar abundance with $\mathrm{C}_{29} \alpha \alpha \alpha 20 \mathrm{R}$ sterane $\left(\mathrm{C}_{27} \approx \mathrm{C}_{29}>\mathrm{C}_{28}\right.$, Figure 3$)$. Actually, this should be attributed to the mixing of migrated hydrocarbons of $\mathrm{C}_{27}$ advantage from mudstone layers with migrated hydrocarbons of $\mathrm{C}_{29}$ advantage from interbedded silicalite layers. It is also supported by field work observation. In the Guangyuan outcrop section, expelled hydrocarbons can be observed in fissures of the silicalite layers. Those migrated hydrocarbons can easily enter the interbedded layers through pores and fissures. Therefore, the biomarker characteristics of $\mathrm{P}_{2} d$ source rock extracts in the GY series actually reflect a kind of mixing between the hydrocarbons from the silicalite layers and interbedded mudstone layers. However, the covalently bound biomarkers in kerogens were not influenced by migrated hydrocarbons because migrated hydrocarbons can hardly incorporate into the kerogen macromolecular structures. Additionally, kerogen powders were extracted by ternary solvent for 2 weeks to sufficiently remove adsorbed hydrocarbons before HyPy experiment. Therefore, the HyPy technology can reduce the interference of migrated hydrocarbons on high-overmature source rocks, and the covalently bound biomarkers released from high-overmature source rocks by HyPy can represent the original characteristics of original organic matter.

The major precursors to pregnane and homopregnane were considered to be hormones, pregnanol and pregnanone [36]. Huang et al. [37] thought that pregnanes and homopregnanes were sourced partly from the precursors in kerogen, and partly from thermal cracking of $\mathrm{C}_{27-29}$ regular steranes. Huang et al. [37] also pointed out that the relative abundance of pregnanes to regular steranes is low at low mature stage $\left(R_{0}<0.42 \%\right)$, and sharply increase at mature stage $\left(R_{\mathrm{o}}>0.42 \%\right)$. Both in the GY and the WC series, the Soxhlet extracts have high abundance of pregnane and homopregnane relative to regular steranes (Figures 3 and 6), because the maturities of source rocks from both outcrop sections are high enough to generate abundant hydrocarbons [37]. In hydropyrolysates, the relative abundances of pregnane to regular steranes are also high in the GY series, but low in the WC series. Large mounts of hydrocarbons were released from kerogen with increasing maturities, which resulted in significant decrease in the covalently bound pregnanes. Therefore the covalently bound pregnanes has almost been removed completely from kerogens of the WC series samples by thermal maturation. However, the GY series samples are still in oil generative window with a great number of pregnanes still incorporated in kerogen. So the hydropyrolysates of the GY series samples still have very high relative abundance of pregnanes. The pregnane/ homopregnane $\left(\mathrm{S}_{21} / \mathrm{S}_{22}\right)$ ratio in extracts of source rocks from both outcrop sections range from 1.05 to 2.46, while $\mathrm{S}_{21} / \mathrm{S}_{22}$ ratio in hydropyrolysates are in the range of $1.42-$ 1.78 , more stable than that in the corresponding Soxhlet extracts. The results suggested that the relative abundance of pregnane and homopregnane released by HyPy decrease with increasing maturity, but the ratio of $S_{21} / S_{22}$ is still quite stable.

The ratio of $\mathrm{C}_{23}$-tricyclic terpane to $\mathrm{C}_{23}$ - and $\mathrm{C}_{24}$-tricyclic terpanes $\left(\mathrm{TT}_{23} /\left(\mathrm{TT}_{23}+\mathrm{TT}_{24}\right)\right)$ remains constant in the Soxhlet extracts and hydropyrolysates (Figures 3, 4, Table 4), indicating that tricyclic terpanes have high resistance to both biodegradation and thermal alteration than pentacyclic terpanes. The ratio of $\mathrm{C}_{23}$-tricyclic terpane to $\mathrm{C}_{30}$-hopane $\left(\mathrm{TT}_{23} / \mathrm{H}_{30}\right)$ is commonly used as source-related parameters in oil generative window [3]. In Soxhlet extracts, the ratio $\mathrm{TT}_{23} / \mathrm{H}_{30}$ of the WC series $(0.21-2.18)$ is higher than that of the GY series $(0.11-0.28)$. Meanwhile, the $\mathrm{TT}_{23} / \mathrm{H}_{30}$ ratio in the hydropyrolysates of the WC series ranges from 0.12 to 0.52 , more stable and lower than that in the corresponding Soxhlet extracts, since tricyclic terpanes are more resistant to thermal degradation than hopanes [3]. The ratio of $\mathrm{C}_{29^{-}}$ norhopane to $\mathrm{C}_{30}$-hopane ratios $\left(\mathrm{H}_{29} / \mathrm{H}_{30}\right)$ is also a commonly used source-related biomarker parameter [3]. $\mathrm{H}_{29} / \mathrm{H}_{30}$ ratio varied in the range of $0.50-1.08$ in the Soxhlet extracts from both outcrop sections. However, $\mathrm{H}_{29} / \mathrm{H}_{30}$ ratio in the hydropyrolysates ranges from 0.76 to 0.93 in mudstones and from 0.67 to 0.73 in silicalites. $\mathrm{H}_{29} / \mathrm{H}_{30}$ in hydropyrolysates seems more stable than in the corresponding Soxhlet extracts. It implies that the covalently bound biomarkers are not significantly altered by thermal maturation when $R_{\mathrm{o}} \leqslant 2.4 \%$ due to the protection of macromolecular structure $[17,35]$.

In conclusion, though the source-related biomarker parameters such as the distribution of $\mathrm{C}_{27-29} \alpha \alpha \alpha 20 \mathrm{R}$ steranes, the ratios of $\mathrm{TT}_{23} / \mathrm{H}_{30}$ and $\mathrm{H}_{29} / \mathrm{H}_{30}$ in Soxhlet extracts were significantly altered by thermal maturation at high-over- 
Table 4 The biomarker parameters of the Soxhlet extracts and hydropyrolysates of $\mathrm{P}_{2} d$ source rocks

\begin{tabular}{|c|c|c|c|c|c|c|c|c|c|c|c|c|c|c|c|c|}
\hline \multirow{3}{*}{$\begin{array}{l}\text { Biomarker } \\
\text { parameters }\end{array}$} & \multicolumn{8}{|c|}{ Soxhlet extracts } & \multicolumn{8}{|c|}{ Hydropyrolysates } \\
\hline & \multicolumn{4}{|c|}{ Mudstone } & \multirow{2}{*}{$\begin{array}{c}\begin{array}{c}\text { Siliceous } \\
\text { Mudstone }\end{array} \\
\text { GY-9 }\end{array}$} & \multicolumn{3}{|c|}{ Silicalite } & \multicolumn{4}{|c|}{ Mudstone } & \multirow{2}{*}{$\begin{array}{c}\begin{array}{c}\text { Siliceous } \\
\text { Mudstone }\end{array} \\
\text { GY-9 }\end{array}$} & \multicolumn{3}{|c|}{ Silicalite } \\
\hline & GY-3 & GY-17 & WC-5 & WC-6B & & GY-8 & WC-4A & WC-6A & GY-3 & GY-17 & WC-5 & WC-6B & & GY-8 & WC-4A & WC-6A \\
\hline $\mathrm{C}_{27} /\left(\mathrm{C}_{27}+\mathrm{C}_{28}+\mathrm{C}_{29}\right)$ & 37 & 43 & 45 & 39 & 40 & 43 & 46 & 36 & 45 & 52 & 51 & 56 & 41 & 34 & 33 & 40 \\
\hline $\mathrm{C}_{28} /\left(\mathrm{C}_{27}+\mathrm{C}_{28}+\mathrm{C}_{29}\right)$ & 19 & 17 & 29 & 31 & 17 & 20 & 30 & 31 & 19 & 16 & 17 & 24 & 21 & 21 & 12 & 14 \\
\hline $\mathrm{C}_{29} /\left(\mathrm{C}_{27}+\mathrm{C}_{28}+\mathrm{C}_{29}\right)$ & 43 & 41 & 26 & 30 & 42 & 38 & 24 & 32 & 36 & 32 & 32 & 21 & 39 & 45 & 55 & 46 \\
\hline $\mathrm{S}_{21} / \mathrm{S}_{22}$ & 1.05 & 1.40 & 2.46 & 1.89 & 1.19 & 1.20 & 1.85 & 1.44 & 1.51 & 1.78 & 1.75 & 1.63 & 1.45 & 1.42 & 1.69 & 1.70 \\
\hline $\mathrm{C}_{27}-\beta \alpha \mathrm{R} / \mathrm{C}_{27} \alpha \alpha \mathrm{R}$ & 0.38 & - & 0.56 & 0.57 & 0.15 & 0.08 & 0.44 & 0.26 & - & 0.13 & 0.19 & 0.22 & - & - & 0.19 & 0.12 \\
\hline $\mathrm{C}_{29} \mathrm{~S}-\beta \beta /(\beta \beta+\alpha \alpha)$ & 0.56 & 0.46 & 0.41 & 0.40 & 0.52 & 0.57 & 0.40 & 0.39 & 0.51 & 0.48 & 0.35 & 0.39 & 0.48 & 0.42 & 0.40 & 0.34 \\
\hline $\mathrm{C}_{29}-20 \mathrm{~S} /(20 \mathrm{~S}+20 \mathrm{R})$ & 0.49 & 0.43 & 0.53 & 0.52 & 0.44 & 0.45 & 0.57 & 0.51 & 0.49 & 0.47 & 0.28 & 0.41 & 0.52 & 0.50 & 0.14 & 0.20 \\
\hline $\mathrm{Ts} /(\mathrm{Ts}+\mathrm{Tm})$ & 0.32 & 0.14 & 0.51 & 0.50 & 0.17 & 0.17 & 0.51 & 0.53 & 0.06 & 0.06 & 0.17 & 0.26 & 0.04 & 0.05 & 0.27 & 0.27 \\
\hline $\mathrm{TT}_{23} /\left(\mathrm{TT}_{23}+\mathrm{TT}_{24}\right)$ & 0.57 & 0.60 & 0.69 & 0.66 & 0.60 & 0.59 & 0.64 & 0.63 & 0.67 & 0.60 & 0.66 & 0.64 & 0.66 & 0.64 & 0.69 & 0.68 \\
\hline $\mathrm{TT}_{23} / \mathrm{H}_{30}$ & 0.21 & 0.15 & 2.18 & 1.16 & 0.28 & 0.11 & 1.19 & 0.21 & 0.25 & 0.27 & 0.33 & 0.21 & 0.17 & 0.12 & 0.52 & 0.27 \\
\hline $\mathrm{H}_{29} / \mathrm{H}_{30}$ & 0.61 & 1.08 & 0.70 & 0.67 & 0.91 & 0.86 & 0.66 & 0.50 & 0.89 & 0.93 & 0.89 & 0.76 & 0.88 & 0.73 & 0.68 & 0.67 \\
\hline
\end{tabular}

mature stages, they were quite stable in the hydropyrolysates. The reason is that the covalently bound biomarkers released by HyPy from kerogen [9,35] and/or bitumen [18] were protected by the macromolecular structure from secondary alterations such as thermal maturation [17,18,35] and biodegradation [38-41]. Additionally, the covalently bound biomarkers released by HyPy from kerogen can eliminate the interference of migrated hydrocarbons between interbedded layers and retain original organic geochemical information.

\subsection{Maturity-related biomarker parameters}

Diasteranes/steranes ratios are commonly used to distinguish petroleum from carbonates or clastic source rocks $[3,42]$. However, high diasteranes/steranes ratios can also result from high thermal maturity [43] and/or heavy biodegradation $[44,45]$. Thus the ratio of $\mathrm{C}_{27}$ cholestane to $\mathrm{C}_{27}$ diacholestane $\left(\mathrm{C}_{27}-\beta \alpha \mathrm{R} / \mathrm{C}_{27}-\alpha \alpha \mathrm{R}\right)$ was calculated and compared (Table 4). In Soxhlet extracts, the ratios $C_{27}-\beta \alpha R /$ $\mathrm{C}_{27}-\alpha \alpha \mathrm{R}$ in the source rocks from the $\mathrm{WC}$ series are higher than that from the GY series, which may be attributed to the maturity differences of the source rocks in the two outcrop sections. Meanwhile, the ratios $C_{27}-\beta \alpha R / C_{27}-\alpha \alpha R$ in the hydropyrolysates are lower than that in the corresponding Soxhlet extracts, implying that the covalently bound biomarkers released by HyPy have lower maturity than the free biomarkers.

Most isomerization ratios related to maturities in free biomarkers obtained by Soxhlet extraction are only valid in the oil generative window or at even lower maturity stage because these ratios reach their end point at high maturities. The $\mathrm{C}_{29}$ sterane isomer ratios of $\mathrm{C}_{29}-\beta \beta /(\beta \beta+\alpha \alpha)$ and $\mathrm{C}_{29^{-}}$ $20 \mathrm{~S} /(20 \mathrm{~S}+20 \mathrm{R})$ are commonly used as maturity-related indicators in oil-generative window [3]. The isomerization at $\mathrm{C}-14$ and $\mathrm{C}-17$ in the $\mathrm{C}_{29}$ regular steranes causes an increase in $C_{29}-\beta \beta /(\beta \beta+\alpha \alpha)$ from 0 to ca. 0.7 (0.67-0.71 end point) with increasing thermal maturity. The $\mathrm{C}_{29}-20 \mathrm{~S} /(20 \mathrm{~S}+20 \mathrm{R})$ ratio rises from 0 to ca. $0.5(0.52-0.55$ end point) with increasing isomerization at $\mathrm{C}-20$ during thermal maturation $[3,31]$. The sterane isomerization ratio $C_{29}-\beta \beta /(\beta \beta+\alpha \alpha)$ in the hydropyrolysates of the $\mathrm{P}_{2} d$ source rocks from the GY series are in the range of $0.34-0.40$ (Table 4), while in the corresponding Soxhlet extracts it is in the range of $0.39-0.41$. Thus the ratio $\mathrm{C}_{29}-\beta \beta /(\beta \beta+\alpha \alpha)$ is in similar range in both hydropyrolysates and Soxhlet extracts. However, the ratio $\mathrm{C}_{29}-20 \mathrm{~S} /(20 \mathrm{~S}+20 \mathrm{R})$ in the hydropyrolysates of the $\mathrm{P}_{2} d$ source rocks of the WC series is in the range of $0.14-0.41$, but in the Soxhlet extracts it is in the range of $0.52-0.57$. Thus for the $\mathrm{P}_{2} d$ source rocks of the WC series, the $\mathrm{C}_{29}-20 \mathrm{~S} /$ $(20 \mathrm{~S}+20 \mathrm{R})$ ratio in the hydropyrolysates is much lower than in the Soxhlet extracts. Such results were also reported in previous catalytic hydropyrolysis studies [12,13,16,17]. In the GY series, the $C_{29}-\beta \beta /(\beta \beta+\alpha \alpha)$ ratio in the hydropyrolysates are in the rang of $0.42-0.51$, while it is in the range of $0.46-0.57$ in the corresponding Soxhlet extracts. The $\mathrm{C}_{29^{-}}$ $20 \mathrm{~S} /(20 \mathrm{~S}+20 \mathrm{R})$ ratio in the hydropyrolysates are in the rang of $0.47-0.52$, but in the Soxhlet extracts it is in the range of $0.43-0.49$. Therefore, the $\mathrm{C}_{29}-\beta \beta /(\beta \beta+\alpha \alpha)$ and $\mathrm{C}_{29}-20 \mathrm{~S} /$ $(20 \mathrm{~S}+20 \mathrm{R})$ ratios in the hydropyrolysates are quite similar to their counterparts in the Soxhlet extracts for the GY series. However, in this study the covalently bound maturity-related biomarkers released by HyPy from kerogen in the overmature WC series show lower maturities than those in the mature GY series. Lockhart et al. [17] also reported that the isomerization ratios of both $\mathrm{C}_{29}$ steranes and $\mathrm{C}_{31}$ hopanes in hydropyrolysates of kerogen of high maturities are lower than those in hydropyrolysates of kerogen of lower matuirties in the $T_{\max }$ range of $407-464^{\circ} \mathrm{C}$. It implied that at high maturity stage the influence of thermal maturation on the covalently bound biomarkers released by HyPy from kerogen may be different from that on the free counterparts in Soxhlet extracts, further study is needed to elucidate how such difference occur. 
Isomerization of $17 \alpha$-hopanes at C-22 occurs earlier than that of regular steranes at C-20 [3]. Hence, the $22 \mathrm{~S} /(22 \mathrm{~S}+$ $22 \mathrm{R}$ ) homohopane isomerization ratio for $\mathrm{C}_{31}-\mathrm{C}_{35}$ hopanes is highly specific for immature to early oil generation stages. Table 4 shows that the isomerization ratios of $\mathrm{C}_{31}$-hopane $\left(\mathrm{H}_{31}-22 \mathrm{~S} /(22 \mathrm{~S}+22 \mathrm{R})\right)$ in Soxhlet extracts and hydropyrolysates are all about 0.6 , very close to the end point. $\operatorname{Tm}\left(\mathrm{C}_{27}\right.$ $18 \alpha$-trisnorhopane $)$ is less stable than Ts $\left(\mathrm{C}_{27} 17 \alpha-\right.$ trisnorhopane), and can be transformed to Ts with increasing maturity $[43,46]$. Ts/(Ts+Tm) ratio depends on both of source and maturity [47]. It is commonly used as maturity indicator of oils from source rocks with the same organic facies [3]. The Ts/(Ts+Tm) ratios in the Soxhlet extracts for the GY series range from 0.14 to 0.32 . It reached its end points (ca. 0.5) in the WC series because of high maturity. There is only trace Ts in the hydropyrolysates for the GY series. It is also reported in previous studies $[10,48]$ that Ts was absent in the hydropyrolysates of low mature kerogen. The $\mathrm{Ts} /(\mathrm{Ts}+\mathrm{Tm})$ ratio of the hydropyrolysates is significantly lower than that of the Soxhlet extracts for the WC series. Previous studies [12,49-51] suggested that the carbon skeletons of bacteriohopanepolyols precursors are cross linked to kerogen geo-macromolecular networks by multiple heteroatomic linkages. Thus, Tm was restrained to be transformed into $\mathrm{Ts}$ in the hydropyrolysates because the covalently bound biomarkers were protected by geo-macromolecular networks. Furthermore, high openness of HyPy pyrolysis system also restricts the conversion of $\mathrm{Tm}$ to Ts by quickly blowing the hydropyrolysates away from the high temperature reactor tube with high pressure hydrogen.

The release of biomarkers from macromolecules (kerogen and bitumen) can lead to the decrease in isomerization ratios [13,18,34,52,53], while isomerization and decomposition (thermal maturation) can lead to the increase in isomerization ratios [54-56]. Previous studies [54-56] demonstrated that the increase in isomerization ratios of hopanes and steranes was mainly resulted from the decomposition of biomarkers rather than direct isomerization. The parameters of maturity-related biomarkers extracted from high-overmature source rocks have already reached their end point [4]. However, the covalently bound biomarkers released by HyPy from kerogen [9,35] and/or bitumen [18] were protected by the macromolecular structure from secondary alterations such as thermal maturation $[17,18,35]$ and biodegradation [38-41]. Meanwhile, the decomposition and isomerization of the covalently bound biomarkers released by HyPy were suppressed because HyPy is a kind of opensystem pyrolysis using high pressure hydrogen as carrier gas. Thus the covalently bound biomarkers released by HyPy from kerogen show lower maturity than their counterparts in Soxhlet extracts. Therefore, the covalently bound biomarkers released by HyPy from kerogen are less altered by thermal maturation than their counterparts in Soxhlet extracts.

\section{Conclusions}

The characteristics of biomarkers in hydropyrolysates and Soxhlet extracts from two Permian Dalong Formation outcrop sections, with similar depositional environments and very different maturities, in Guangyuan and Wangcang areas were compared and discussed. Based on these results, the following conclusions can be made:

(1) Considerable amount of covalently bound biomarkers released by HyPy from high-overmature Permian Dalong Formation source rock kerogen in the Wangcang outcrop section $\left(R_{0} \leqslant 2.4 \%\right)$ can meet the requirement of instrumental analysis. The yields of EOM by HyPy are 37-168 times those by Soxhlet extraction. In hydropyrolysates, saturated hydrocarbons fraction make $9.4 \%-27.9 \%$ of total EOM for GY series, contrasted to $0.2 \%-2.7 \%$ for the WC series. It implied that there are few aliphatic structures in the kerogen structure at high-overmature stages due to severe decomposition and condensation.

(2) Thermal maturation have much lower influence on the covalently bound biomarkers in kerogens than on free biomarkers in Soxhlet extracts. The source-related biomarker parameters such as the distribution of $\mathrm{C}_{27-29}$ $\alpha \alpha \alpha 20 \mathrm{R}$ steranes, the ratios of the $\mathrm{TT}_{23} / \mathrm{H}_{30}$ and the $\mathrm{H}_{29} / \mathrm{H}_{30}$ were quite stable in the hydropyrolysates of various maturities. Most of the maturity-related biomarker parameters such as the isomerization ratios of hopanes and steranes were also lower than their counterparts in Soxhlet extracts.

(3) The free biomarkers in Soxhlet extracts of high-over mature source rocks can hardly be correlated to the corresponding covalently bound biomarkers due to severe thermal alterations. The application of HyPy to study of biomarkers can reduce the thermal maturation effect on covalently bound biomarkers $\left(R_{0} \leqslant 2.4 \%\right)$ to a greater extent. The free biomarkers in Soxhlet extracts of source rocks that are interbedded with layers of different lithology can hardly be correlated to the corresponding covalently bound biomarkers due to interference of migrated hydrocarbons between interbedded layers. The application of HyPy to study of biomarkers also can reduce the interference of migrated hydrocarbons. The covalently biomarkers released by HyPy can represent the original organic geochemical information and are useful in the study of biomarker geochemistry and oil-source correlation on high-overmature source rocks, providing a new approach for the geochemistry study of high-overmature source rocks in South China.

This work was supported by the National Science and Technology Major Project (2011ZX05008-002 and 2011ZX05005-001). This is contribution No. IS-1516 from GIGCAS. We thank Prof. Wenhui Liu, Drs. Tenger and Jie Wang from Wuxi Institute of Petroleum Geology, SINOPEC for all kinds of help in this research, Profs. Lizeng Bian from Nanjing University and Chengyuan Wang from Nanjing Institue of Geology and Palaeontology, Chinese Academy of Sciences for their assistants in sampling process, Prof. Jialan Lu, Huashan Chen, Yinhua Pan and Fang Yuan from State Key 
Laboratory of Organic Geochemistry, Guangzhou Institue of Geochemistry, Chinese Academy of Sciences for data analysis and laboratory assistance.

1 Eglinton G, Scott P M, Belsky T, et al. Hydrocarbons of biological origin from a one-billion-year-old sediment. Science, 1964, 145: 263-264

2 Eglinton G, Calvin M. Chemical fossils. Sci Am, 1967, 261: 32-43

3 Peters K E, Walters C C, Moldowan J M. The Biomarker Guide, Biomarkers and Isotopes in Petroleum Exploration and Earth History. 2nd ed. New York: Cambridge University Press, 2005. 1-699

4 Liang D G, Chen J P. Oil-source correlations for high and overmatured marine source rocks in South China (in Chinese). Petrol Explor Dev, 2005, 32: 8-14

5 Liang D G, Guo T L, Chen J P, et al. Some progresses on studies of hydrocarbon generation and accumulation in marine sedimentary regions, Southern China (Part2): Geochemical characteristics of four suits of regional marine source rocks, South China (in Chinese). Mar Origin Petrol Geol, 2009, 14: 1-15

6 Zhao M J, Zhang S C, Zhao L, et al. Geochemistry and genesis of bitumen in paleo-oil reservoir in the Nanpanjiang Basin, China (in Chinese). Acta Geol Sin, 2006, 80: 893-902

7 Zhao M J, Zhang S C, Zhao L, et al. Geochemical features and genesis of the natural gas and bitumen in paleo-oil reservoirs of Nanpanjiang Basin, China. Sci China Ser D-Earth Sci, 2007, 50: 689-701

8 Sun Y G, Meredith W, Snape C E, et al. Study on the application of hydropyrolysis technique to the description of organic matter in highly mature source rocks (in Chinese). Oil Gas Geol, 2008, 29: 276-282

9 Love G D, Snape C E, Carr A D, et al. Release of covalently-bound alkane biomarkers in high yields from kerogen via catalytic hydropyrolysis. Org Geochem, 1995, 23: 981-986

10 Love G D, Snape C E, Carr A D, et al. Changes in molecular biomarker and bulk carbon skeletal parameters of vitrinite concentrates as a function of rank. Energ Fuel, 1996, 10: 149-157

11 Love G D, McAulay A, Snape C E, et al. Effect of process variables in catalytic hydropyrolysis on the release of covalently bound aliphatic hydrocarbons from sedimentary organic matter. Energ Fuel, 1997, 11: 522-531

12 Murray I P, Love G D, Snape C E, et al. Comparison of covalently bound aliphatic biomarkers released via hydropyrolysis with their solvent-extractable counterparts for a suit of Kimmeridge clays. Org Geochem, 1998, 29: 1487-1505

13 Bishop A N, Love G D, McAulay A D, et al. Release of kerogenbound hopanoids by hydropyrolysis. Org Geochem, 1998, 29: 9891001

14 Zhou J, Li S, Yue C, et al. Release and analysis of the biomarkers combined by covalent bound from higher evolved organic sediment (in Chinese). Acta Petrol Sin, 2006, 22: 83-88

15 Zhou J W, Li S Y, Zhong N N. Study on hydropyrolysis of sedimentary organic matter and geochemical information of hydropyrolysates. J Fuel Chem Tech, 2007, 35: 648-654

16 Bowden S R, Farrimond P, Snape C E, et al. Compositional differences in biomarker constituents of the hydrocarbon, resin, asphaltene and kerogen fractions: An example from the Jet Rock (Yorkshire, UK). Org Geochem, 2006, 37: 369-383

17 Lockhart R S, Meredit W, Love G D, et al. Release of bound aliphatic biomarkers via hydropyrolysis from Type II kerogen at high maturity. Org Geochem, 2008, 39: 1119-1124

18 Liao Y H, Fang Y X, Wu L L, et al. The characteristics of the biomarkers and $\delta^{13} \mathrm{C}$ of $n$-alkanes released from thermally altered solid bitumens at various maturities by catalytic hydropyrolysis. Org Geochem, 2012, 46: 56-65

19 Wang Y G, Wen Y C, Hong H T, et al. Dalong Formation found in Kaijiang-Liangping ocenic trough in the Sichuan Basin (in Chinese). Nat Gas Ind, 2006, 26: 32-36

20 Wang Y G, Wen Y C, Hong H T, et al. Petroleum geological characteristics of deep water deposits in Upper Permian-Lower Triassic trough in Sichuan basin and adjacent areas (in Chinese). Oil Gas Geol,
2006, 27: 702-714

21 Tenger, Qin J Z, Fu X D, et al. Basic conditions of marine hydrocarbon accumulation in Northwest Sichuan Basin-High quality source rocks (in Chinese). Petrol Geol Exp, 2008, 30: 478-483

22 Li H J, Xie X N, Lin Z L, et al. Organic matter enrichment of Dalong Formation in Guangyuan area of the Sichuan Basin (in Chinese). Geol Sci Technol Inf, 2009, 28: 98-103

23 Ma Y S, Mou C L, Tan Q Y, et al. A discussion on Kaijiang-Liangping ocean trough (in Chinese). Oil Gas Geol, 2006, 27: 326-331

24 Cai X F, Zhang Z F, Peng X F, et al. Depositional characteristics of the Dalong Formation and the related potential hydrocarbon source rocks of Hubei, Hunan, Guizhou and Guangxi Regions (in Chinese). Earth Sci J Chin Univ Geosci, 2007, 32: 774-780

25 Feng Z Z. Sedimentary Petrology (in Chinese). Beijing: Petroleum Industry Press, 1994. 1-326

26 Sweeney J J, Burnham A K. Evaluation of a simple method of vitrinite reflectance based on chemical kinetics. AAPG Bull, 1990, 74: $1559-1570$

27 Zhang Y D, Jiang A Z, Sun Y G, et al. Stable carbon isotope compositions of isoprenoid chromans in Cenozoic saline lacustrine source rocks from the Western Qaidam Basin, NW China: Soure implication. Chin Sci Bull, 2012, 57: 1013-1023

28 Liao Y H, Geng A S, Huang H P. The influence of biodegradation on resins and asphaltenes in the Liaohe Basin. Org Geochem, 2009, 40: 312-320

29 Rohmer M, Poralla K. Prokaryotic hopanoids and other polyterpenoid sterol surrogates. Annu Rev Microbiol, 1987, 41: 301-333

30 Seifert W K, Moldowan J M, Demaison G J. Source correlation of biodegraded oils. Org Geochem, 1984, 6: 633-643

31 Seifert W K, Moldowan J M. Use of biological markers in petroleum exploration. In: Johns R B, ed. Methods in Geochemistry and Geophysics. New York: Elsevier, 1986. 261-290

32 Peters K E, Moldowan J M, Driscole A R, et al. Origin of Beatrice oil by co-sourcing from Devonian and Middle Jurassic source rocks, Inner Moray Firth, U.K. AAPG Bull, 1989, 73: 454-471

33 Peters K E, Snedden J W, Sulaeman A, et al. A new geochemical-stratigraphic model for the Mahakam Delta and Makassar slope, Kalimantan, Indonesia. AAPG Bull, 2000, 84: 12-44

34 Lu S T, Ruth E, Kaplan I R. Pyrolysis of kerogens in the absence and presence of montmorillonite- $\mathrm{I}$. The genertation, degradation and isomerization of steranes and triterpanes at 200 and $300^{\circ} \mathrm{C}$. Org Geochem, 1989, 14: 491-499

35 Love G D, Snape C E, Fallick A E. Differences in the mode of incorporation and biogenicity of the principal aliphatic constituents of a Type I oil shale. Org Geochem, 1998, 28: 797-811

36 de Leeuw J W, Bass M. Early diagenesis of steroids. In: Johns R B, ed. Biological Markers in the Sedimentary Record. Amsterdam: Elsevier, 1986. 102-127

37 Huang D F, Zhang D J, Li J C. On origin of 4-methyl steranes and pregnanes (in Chinese). Petrol Explor Dev, 1989, 3: 8-15

38 Rubinstein I, Spyckerelle C, Strausz O P. Pyrolysis of asphaltenes: A source of geochemical information. Geochim Cosmochim Acta, 1979, 43: 1-6

39 Behar F, Pelet R, Roucache J. Geochemistry of asphaltenes. Org Geochem, 1984, 6: 587-595

40 Cassani F, Eglinton G. Organic geochemistry of Venezuelan extra-heavy oils: 1 . Pyrolysis of asphaltenes: A technique for the correlation and maturity evaluation of crude oils. Chem Geol, 1986, 56: $167-183$

41 Russell R A, Snape C E, Meridith W, et al. The potential of bound biomarker profiles released via catalytic hydropyrolysis to reconstruct basin charging history for oils. Org Geochem, 2004, 35: 1441-1459

42 Mello M R, Telnaes N, Gaglianone P C, et al. Organic geochemical characterization of depositional paleoenvironments of source rocks and oils in Brazilian marginal basins. Org Geochem, 1988, 13: 31-45

43 Seifert W K, Moldowan J M. Applications of sterances, terpanes, and monoaromatics to the maturation, migration, and source of crude oils. Geochim Cosmochim Acta, 1978, 42: 77-95

44 Seifert W K, Moldowan J M. The effect of biodegradation on ster- 
anes and terpanes in crude oils. Geochim Cosmochim Acta, 1979, 43: 111-126

45 Goodarzi F, Brooks P W, Embry A F. Regional maturity as determined by organic Petrography and geochemistry of the Schei Point Group (Triassic) in the western Sverdrup Basin, Canadian Arctic Archipelago. Mar Petrol Geol, 1989, 6: 290-302

46 Kolaczkowska E, Slougui N E, Watt D S, et al. Thermodynamic stability of various alkylated, dealkylated and rearranged $17 \alpha$ - and $17 \beta-$ hopane isomers using molecular mechanics calculations. Org Geochem, 1990, 16: 1033-1038

47 Moldowan J M, Dundararaman P, Schoell M. Sensitivity of biomarker properties to depositional enviroment and/or source input in the Lower Toarcian of S. W. Germany. Org Geochem, 1986, 10: 915-941

48 Meredith W, Snape C E, Carr A D, et al. The occurrence of unusual hopenes in hydropyrolysates generated from severely biodegraded oil seep asphaltenes. Org Geochem, 2008, 39: 1243-1248

49 Mycke B, Michaelis W. Molecular fossils from chemical degradation of macromolecular organic matter. Org Geochem, 1986, 10: 847-858

50 Michaelis W, Richnow H H, Jenisch A, et al. Structural inferences from organic geochemical coal studies. In: Ittekkot V, Kempe S,
Michaelis W, et al., eds. Facets of Modern Biogeochemistry. Heidelberg: Springer Verlag, 1989. 389-402

51 Hofmann I C, Hutchison J, Robson J N, et al. Evidence for sulphide links in a crude oil asphaltene and kerogens from reductive cleavage by lithium in ethylamine. Org Geochem, 1992, 19: 371-387

52 Pan C C, Peng D H, Zhang M, et al. Distribution and isomerization of $\mathrm{C}_{31}-\mathrm{C}_{35}$ homohopanes and $\mathrm{C}_{29}$ steranes in Oligocene saline lacustrine sediments from Qaidam Basin, Northwest China. Org Geochem, 2008, 39: 646-657

53 Peters K E, Moldowan J M. Effects of source, thermal maturity, and biodegradation on the distribution and isomerization of homohopanes in petroleum. Org Geochem, 1991, 17: 47-61

54 Larcher A V, Alexander R, Kagi R I. Differences in reactivities of sedimentary hopane diastereomers when heated in the presence of clays. Org Geochem, 1988, 13: 665-669

55 Dzou L I P, Noble R A, Senftle J T. Maturation effects on absolute biomarker concentration in a suite of coals and associated vitrinite concentrates. Org Geochem, 1995, 23: 681-697

56 Farrimond P, Taylor A, Telnet N. Biomarker maturity parameters: The role of generation and thermal degradation. Org Geochem, 1998, 29: 1181-1197

Open Access This article is distributed under the terms of the Creative Commons Attribution License which permits any use, distribution, and reproduction in any medium, provided the original author(s) and source are credited. 